\title{
OPEN
}

\section{Author Correction: Evaluation of T1 relaxation time in prostate cancer and benign prostate tissue using a Modified Look-Locker inversion recovery sequence}

\section{Alexander D. J. Baur, Carla M. Hansen, Julian Rogasch, Helena Posch, Sefer Elezkurtaj, Andreas Maxeiner, Katharina Erb-Eigner \& Marcus R. Makowski}

Correction to: Scientific Reports https://doi.org/10.1038/s41598-020-59942-z, published online 20 February 2020

The Acknowledgements section in this Article was omitted. The Acknowledgements section should read:

"We acknowledge support from the German Research Foundation (DFG) and the Open Access Publication Funds of Charité - Universitätsmedizin Berlin."

(c) (i) Open Access This article is licensed under a Creative Commons Attribution 4.0 International License, which permits use, sharing, adaptation, distribution and reproduction in any medium or format, as long as you give appropriate credit to the original author(s) and the source, provide a link to the Creative Commons license, and indicate if changes were made. The images or other third party material in this article are included in the article's Creative Commons license, unless indicated otherwise in a credit line to the material. If material is not included in the article's Creative Commons license and your intended use is not permitted by statutory regulation or exceeds the permitted use, you will need to obtain permission directly from the copyright holder. To view a copy of this license, visit http://creativecommons.org/licenses/by/4.0/.

(C) The Author(s) 2020 